University of the Pacific

Scholarly Commons

2014

\title{
Enforcing Desegregation: A Case Study of Federal District Court Power and Social Change in Macon County Alabama
}

Brian K. Landsberg

Pacific McGeorge School of Law

Follow this and additional works at: https://scholarlycommons.pacific.edu/facultyarticles

Part of the Civil Rights and Discrimination Commons

\section{Recommended Citation}

48 Law \& Soc'y Rev. 867

This Article is brought to you for free and open access by the McGeorge School of Law Faculty Scholarship at Scholarly Commons. It has been accepted for inclusion in McGeorge School of Law Scholarly Articles by an authorized administrator of Scholarly Commons. For more information, please contact mgibney@pacific.edu. 


\title{
Enforcing Desegregation: A Case Study of Federal District Court Power and Social Change in Macon County Alabama
}

\author{
Brian K. Landsberg
}

\begin{abstract}
This case study of Lee v. Macon County Board of Education demonstrates that a federal district court in Alabama, enforcing Brown v. Board of Education, brought about significant social change despite constraints on the courts. The court's application of Brown played a decisive role in ending the racial caste system in this Alabama black belt county. The court, by adding the United States Department of Justice as a party, overcame constraints that had precluded the executive branch from pursuing school desegregation. Change came through the courts before Congress legislated against school segregation. Seekers of social change must evaluate the constraints on the courts relative to the constraints on the other branches and levels of government.
\end{abstract}

This article grows out of a larger project. Thanks to Anne Bloom and participants in a Pacific McGeorge Works in Progress program. Thanks to Steve Pollak and Dorothy Landsberg for comments on early drafts, and to Stephen L. Wasby for his ongoing advice both on this article and on the larger project. The editors and reviewers for Law and Society Review contributed valuable suggestions. I benefited also from feedback on a related manuscript at the Midwest Political Science Association meeting in 2013, especially from Ira Strauber and Thomas Keck. Thanks to archivists at Tuskegee Institute, Library of Congress, National Archives and Records Administration College Park, Kennedy Presidential Library, and Alabama State Archives. A number of research assistants have helped on this project: Jocelyn Blinn, Keith Banks, Michael Heumann, Jacqueline Hassell, and Abby Maurer. Robert Mayville provided helpful research assistance on this article. Finally, Joseph M. Bagley generously shared with me his extensive research on Lee v. Macon County Board of Education. 


\section{INTRODUCTION}

This article closely examines Lee v. Macon County Board of Education, a case that grew from a challenge to school segregation in a small Alabama county and became the vehicle for statewide school desegregation. In its examination, the article, following the suggestion of Schultz \& Gottlieb (1996: 90), deviates from the methodology used by Rosenberg and examines the role of the judiciary in school desegregation at the micro level. It explores the question whether and how lower court enforcement of a Supreme Court decision such as Brown v. Board of Education may bring about social change even though, "in a government in which [powers] are separated from each other, the judiciary... will always be the least dangerous...”" (Hamilton 1788). To what extent are the courts constrained by "the inability to develop appropriate policies and ... lack of powers of implementation?” (Rosenberg 2008:10).

Rosenberg lists three constraints on the ability of courts to produce meaningful social change: the limited nature of constitutional rights, the lack of judicial independence, and the judiciary's lack of powers of implementation. The second constraint, he says, can be overcome only with support from Congress and the executive, and the third only with support from some citizens or low levels of opposition from all citizens. (Rosenberg, 35-36) Yet Lee v. Macon County Board of Education produced meaningful social change despite the lack of 
support from Congress and a high level of opposition from whites in Macon County.

To those who seek instruments of social change, the question, "Can courts bring about social change?” is the wrong question. As McCann (1994:136) demonstrates, social change depends upon the confluence of several forces. Opponents of the racial caste system engaged in a multi-pronged attack in which the courts were an essential element. Litigation, pressure on the executive branch, lobbying Congress for legislation, marches, boycotts, sit-ins, Freedom Rides, and voter registration campaigns were the tools. The courts enabled many of these methods, even encouraging some of them, and they began enforcing Brown before Congress’ landmark Civil Rights Act of 1964 empowered federal agencies to enforce school desegregation. John Doar succinctly summarized: “Look, if you're going to bring about a big cultural change in this country, you need the three branches of the federal government to work together...” (Landsberg 2013:304; see also, Cummings (2013:185), McCann (1992:728), and Epstein \& Walker (2007:123)).

Examining litigation for social change through the lens of Lee v. Macon in its early phases reveals the complex interaction of the district court, the proponents of social change, the state and local governments, the federal executive branch, and the Congress. This article covers the first two years of the case, 1963-1965. By 1966 the enforcement of the Civil Rights Act of 1964 
reinforced the judicial enforcement of Brown. But implementation of Brown in Alabama began when Congress had done nothing either to implement or interfere with the Brown decision.

This article examines the difficult question of causation: Did Brown bring about social change, or would the schools of the South, as Klarman seems to suggest, have desegregated faster if the Court had not decided Brown? It also examines whether the original objectives of the proponents of social change were met by the litigation. Any number of cases could serve as the vehicle for an empirical study of these questions, but Lee v. Macon County Board of Education provides a more comprehensive set of issues than some. It addresses state interference with court-ordered desegregation, tuition grant statutes and their constitutionality, and the United States as a litigating amicus curiae, as well as the role of the state government, the Department of Justice, and the Department of Health Education and Welfare in bringing about desegregation (Lee v. Macon County Board of Education 1967).

Addressing the issues through this concrete case provides a perspective missing in Rosenberg's analysis. As Vecera recently demonstrated, close examination of specific elements may be more informative than reliance on gross measures such as polling. Moreover, Rosenberg’s discussion of Brown’s influence on public opinion presents quantitative but not qualitative data. He does not consider the extent to which Brown led opinion leaders to, as Vecera puts it, 
adopt "a rhetoric that emphasized constitutional claims...." (Vecera, 235) Yet, as Lee v. Macon County Board of Education demonstrates, the primacy of the constitutional claim after Brown was decided transformed the issue from one of abstract social policy regarding equal education to one of enforcing the Constitution.

Lee began in 1963 as an effort by African Americans in a small rural county to achieve equal educational opportunity. Alabama Governor George Wallace's interference with the ensuing federal court order transformed it into the vehicle for achieving statewide school desegregation. This district court case concretizes the impact of the Supreme Court's decision in Brown v. Board of Education and shows how the lower court advanced social change (Mack 2012:1040, reviewing Brown-Nagin 2011). The case also illuminates the role of the federal government in school desegregation.

Change began with Brown's holding that the separate but equal doctrine in the public schools is unconstitutional. However, articulation of a new legal norm does not necessarily change behavior. One may expect resistance, especially where the legal norm differs from the social or religious norm. As Hall (15-18) points out, the courts' ability to bring about change is relatively high when they need not rely on other political actors to implement their decisions; school desegregation, however, could be achieved only through elected school boards carrying out the Brown mandate. Given the political resistance to Brown in the 
Deep South, how could the courts ensure compliance? Macon County’s experience shows that private plaintiffs, determined to secure equal education under Brown, were able to gain relief from a skilled federal judge, who enlisted the willing aid of the U.S. Attorney General at a time when help from Congress was but a dim hope and the Alabama state government was an implacable foe.

This study accepts Rosenberg's model of constrained and dynamic court, but suggests that it is not sufficient to examine the question at the macro level, as Rosenberg does, but that deeper understanding comes from adding analysis at the micro level. Rather than relying on regional and national desegregation statistics, review of news coverage, and polling data, the study examines experience in one school system. It considers the tools available to the seekers of social change in Macon County and explains how they were deployed and how the trial court expanded those tools. This method of analysis helps put the national statistics and polling data into perspective. 


\section{MACON COUNTY, THE SCHOOL BOARD, AND AFRICAN}

\section{AMERICANS}

The Birmingham News once characterized Macon County as the "guinea pig of race relations in Alabama” (Taylor 1951). The County, located in Alabama’s midsection, would have been an ordinary rural Black Belt county but for the African American community of middle-class professionals centered around the Tuskegee Institute and the Tuskegee Veterans Hospital. Black Macon Countians' interest in equal education began before Brown v. Board of Education. In 1934 Charles Johnson, a noted African American sociologist, had written about the county: "It has been impossible to escape the force of tradition, as represented in the customs established under the institution of slavery, and adhered to by the white population in their relation to the Negroes, and by the Negroes in relation to themselves” (Johnson 1934:208). By the 1930’s, though, even rural Macon County African Americans were beginning to stress the value of education (Johnson 1934:134, 156).

Before Brown, Macon County African Americans faced the long-standing Alabama law requiring segregation of the races, “firmly entrenched in American constitutional law.” (Legislative Reference Service 1954). And they faced a voter registration law that allowed systematic discrimination against African American applicants to vote; a hostile white political ruling class; and limited options for redress. State courts were "places in which the Negro could count on 
little consideration...” (Cash 1941:412). The education system for African Americans was based on the perception of the ruling whites that "Negro education ... will enable us to make sure that he acquires no dangerous notions, to control what he is taught, to make sure that he is educated to fit into, and to stay in, his place” (Cash 1941:181-83). Absent Brown, the South was highly unlikely to desegregate voluntarily, given its "all too great attachment to racial values and a tendency to justify cruelty and injustice in the name of those values...” (Cash 1941:426).

In 1950 the leading Macon County civil rights organization, the Tuskegee Civic Association (TCA), published a chart showing that per pupil expenditure for Macon County whites was \$255.02 compared with \$88.07 per black student, a threefold disparity. Capital outlay per pupil reflected an even greater, tenfold disparity: \$85.59 per white and \$7.93 per black (Tuskegee Civic Association 1950). The following January an African American mother asked the county superintendent to either provide her son at the black high school in Tuskegee a geometry course or allow him to take that one course at the nearby all-white Tuskegee High School. Dr. C.G. Gomillion, for the TCA, then sent a petition that told the school board that its actions denied black children "equal protection of the laws secured by the Fourteenth Amendment to the Constitution of the United States” (Cobb 1951; Norrell 1985:81). 
Although Macon County African Americans embraced the importance of Supreme Court decisions "trying to implement the value of equality of opportunity, and to rectify the unfortunate decision of the 1896 Court" (Gomillion 1959), the first priority of the TCA was to secure the right to vote. Not until Federal District Judge Frank M. Johnson had decisively acted to enforce the Supreme Court rulings in the TCA's case challenging the gerrymander of Tuskegee and ordered relief in the Justice Department’s Macon County voting rights case did the TCA devote resources to school desegregation. That the school desegregation suit was brought in early 1963 suggests the powerful influence of the Supreme Court's decisions in Brown and the two recent voting rights cases.

Within two months of the 1955 decision in Brown II, thirty-two African American parents petitioned the Macon County Board of Education asking for desegregation. The State Senator from Macon County, Sam Engelhardt, responded, "We will have segregation in the public school of Macon County or we will have no schools,” and the chairman of the Board worried that the petition "would whip up 'a great deal of resentment”' (“Thirty-Two Negroes Ask for School Desegregation in Macon County” 1955). In 1955, the TCA sent telegrams to Governor Folsom protesting state legislation to prevent Brown v. Board of Education from going into effect and in 1956 published a letter in a local newspaper asking the school board to consider desegregation, and other appeals 
followed (Guzman 1984:150-51). This made inevitable a conflict between the federal court's duty under the Constitution to enforce Brown and the state government led by the Alabama governor arguing states’ rights.

White resistance to desegregation ran high throughout Alabama, especially in the Black Belt, where white students were both heavily outnumbered and tended to receive highly favored access to educational resources. Senator Engelhardt had successfully laid the foundation for state support for an all-white private school where parents could send their children if and when the inevitable desegregation finally took place. As Governor Patterson took office in 1959, the TCA became concerned about threats of Ku Klux Klan violence if the schools were desegregated (Buford 1959). As Peltason (1961:58) noted in the time period, "Segregationists know that if they can keep Negroes from suing in federal courts they can continue to operate segregated institutions. They have not hesitated therefore to intimidate Negro plaintiffs.”

\section{THE DESEGREGATION CASE AND THE UNITED STATES DEPARTMENT OF JUSTICE}

One major constraint on the courts is that they act only in response to litigation. Until a case is filed, the court is powerless. In 1963, any suit to desegregate would have to come from private plaintiffs, not the United States government. Had the United States brought a criminal prosecution for willful 
violation of constitutional rights a predominantly white Alabama jury, would not have convicted (Carr 1947:138-146). Congress had refused to authorize the U.S. Attorney General to bring civil suits to remedy denials of constitutional rights (Peltason 1961:54-55). Moreover, an Alabama federal court rejected the Attorney General's attempt to sue on behalf of the children of the federal employees at the V.A. hospital (U.S. v. Madison County Board of Education 1963). John Doar later explained: “We didn't have any jurisdiction to bring school cases at that time, and we only entered school cases as friends of the court, or if there was a violation of a federal court order” (Eyes on the Prize 1985).

It fell to the African American parents to undertake the litigation. In September 1962 the TCA petitioned the Macon County School Board to develop a desegregation plan. The School Board did not respond (Tuskegee Civic Association 1965). In early January 1963 the Association hired Fred Gray, who filed suit on January 28, 1963, representing parents of sixteen school age children from eight Tuskegee families. The suit was assigned to the only judge in the federal district court in Montgomery, Frank M. Johnson. Judge Johnson had already heard two voting rights cases involving Macon County and so was familiar with the operation of the racial caste system there (Bass 1993:209). Johnson, a former United States Attorney, had developed respect for the Civil Rights Division of the Department of Justice, and within days of the filing he 
notified the Division that he planned to ask the United States to participate as amicus curiae with the rights of a party (Marshall 1963).

That district courts may summon the help of a litigating amicus suggests that the institutional weaknesses of the "constrained court" can be overcome by a determined and imaginative judge, even in a case raising “unpopular lateral issues,” where implementation of court orders depends on cooperation from officials outside the court system (Rosenberg 2008:10; Hall 2011:17,127). True, the government may always decline the invitation to participate, but precedent and the normal commitment of the executive to maintain law and order generally lead the government to participate as requested (Brownell 1956).

Although the defendants filed a perfunctory motion asking the court to dismiss the Macon County desegregation case, the law was clear and the facts of segregation indisputable. When the suit was filed in 1963, no school in the state enrolled white and black students. Most Alabama whites were dead set against desegregation. The new Governor, George C. Wallace, had declared at his inauguration in January of 1963, "I draw the line in the dust and toss the gauntlet before the feet of tyranny and I say segregation now, segregation tomorrow, segregation forever.” He gave assurance that he would fight the federal government and the federal courts: "That from this day, from this hour . . . from this minute ... we give the word of a race of honor that we will tolerate their boot 
in our face no longer ... . and let those certain judges put that in their opium pipes of power and smoke it for what it is worth” (Wallace 1963a).

As the fall semester drew nearer, events unfolded at an increasingly intense pace. The actors included the plaintiffs, the school board, the United States through its lawyers, the Macon Countians who wanted to fight desegregation, the Governor, and Judge Johnson.

In July 1963, the plaintiffs filed a motion for immediate relief. A few days later the court of appeals ordered immediate relief in separate school desegregation cases in Birmingham and Mobile. Thus, the court in Lee v. Macon knew both that it was required to act and that Governor Wallace was likely to interfere. So the following week, Judge Johnson not only joined the U.S. as a friend of the court, but took the important additional step of appointing the United States as a party. He justified this unusual order by stating "that the public interest in the administration of justice and in preserving law and order and in protecting the authority and integrity of the lawfully constituted courts of the United States made it appropriate and necessary that the United States of America be designated to appear and participate as a party ” (Lee v. Macon County Board of Education 1964:744-745). This formulation altered Judge Wright's language in bringing the United States into the New Orleans case: "in order to maintain and preserve the due administration of justice and the integrity of the judicial processes of the United States” (Bush v. Orleans Parish School Board 1961:876). 
The addition of the words "law and order" transformed the role of the United States from protector of court orders to protector of law itself, which in the context of school desegregation cases meant protector of constitutional rights, the very role that Congress had twice denied the Department of Justice.

At a hearing on August 13, 1963, the evidence showed that the school district continued to maintain a racially-segregated school system. However, unlike most other deep south school districts, the defendants offered to prepare a desegregation plan by December 1963 and were "at the present time ready and willing to start immediately in the desegregation of the schools of Macon County, Alabama, ... [under] the Alabama School Placement Law, without any racial discrimination” (Lee v. Macon County Board of Education 1963:300). The court ruled in favor of the plaintiffs, enjoining segregation of the schools, requiring non-racial assignments under the pupil placement law, and requiring a plan for desegregation to be filed by December. At the request of David Norman, an attorney for the United States, the court ordered the defendants to report to the court on their actions on applications for assignment under the pupil placement law (Lee v. Macon County Board of Education 1963, Tentative Findings and Conclusions Aug. 27). The reporting requirement would help the court and the parties to ensure compliance. This was an early sign that the court, with the backing of the Attorney General, would vigorously enforce its orders. 
After the hearing, the parties and Judge Johnson privately discussed next steps. They agreed that the initial black student applications would be only to attend Tuskegee High School, because "everyone agreed that the Notasulga and Shorter areas [where the other white schools were located] are bad areas and that integration would undoubtedly go smoother in the Tuskegee school.” Judge Johnson then met privately with Norman, and told him that Governor Wallace was likely to interfere with desegregation at one of the four school districts that were to desegregate that fall and that the Justice Department needed to "keep our intelligence forces going so that we will be really ready if there is any trouble.” He also wanted the Justice Department to stay in close contact with the Macon County superintendent, to help him resist pressure to violate the order (Norman 1963).

After Judge Johnson entered the desegregation order, John Doar, second in command of the Civil Rights Division, wrote a memorandum that reflected an increasingly proactive role of the United States. He proposed to return to Tuskegee the next morning "to go over the list of applicants to determine that the Board has been fair with respect to acceptance and rejection.” He acknowledged that "this puts the Department of Justice deep into the supervision of the school system prior to any objections by the Negroes," and he noted that this "takes the burden of policing the school board off the back of the Negroes' attorney.” Another reason for taking on this role was "This is what Judge Johnson wants." 
He deemed the deep involvement of the Department of Justice as necessary, because the plaintiffs, court, and school board "face tremendous problems in working out a satisfactory school system in Macon County (5 Negro school children for every one white child).” Finally, Doar argued, “The experience that we gain here will be useful in counseling with the Board and the Court on a feasible school desegregation plan” (Doar 1963).

This memo reflects optimism, hard-nosed analysis of the situation, and a view that Department of Justice participation in this case must go beyond enforcing court orders and must reach into shaping the relief in the case. The rest of the memorandum, devoted to security issues and community relations, showed that Doar was creating close relationships with both the black and white leadership, including local law enforcement. The Department of Justice was now acting more like a party than an amicus.

Twenty-seven African Americans applied to attend white schools, the Tuskegee News reported. The story noted that observers believed the pupil placement law could not be used to maintain segregation (Tuskegee News 1963). The school board, after consulting with the Tuskegee mayor and some city council members, unanimously voted to comply with the order. The day after the March on Washington, the Board approved the enrollment of thirteen of the fortyeight African American students who had by then applied to attend Tuskegee High School, where 550 white students were enrolled. The Superintendent of 
Schools, C.A. Pruitt, did “not anticipate any trouble,” and, he added, local police could take care of any problems that might occur (Harris 1963).

After the school board selected the thirteen African American students to attend Tuskegee High School, the students met regularly with attorney Fred Gray and community leaders to prepare themselves for integration. They were aware of what had happened in Little Rock six years earlier, and the grownups at the meeting "would tell us things like you can expect to be hollered at, you can expect to maybe even be spit upon. But you are to take no action.” Then, as Willie Wyatt recounts, John Doar introduced himself and explained "that the Justice Department is there for our benefit, to look out for us, for our security.” Wyatt was impressed that the federal government was taking an interest in the case and him as an individual (Bagley 2012).

The Department of Justice thus viewed its role in the case as extending well beyond the giving of advice or presenting evidence in court. While the students were not in an attorney-client relationship with the Department of Justice, its lawyers took on a responsibility to insure that the students' rights were protected. 


\section{THE STATE'S ROLE}

The Governor had promised “segregation forever.” His predecessor, John Patterson, had successfully followed a strategy of delay, but that strategy had begun to run its course. Not only had Judge Johnson ordered desegregation of the Macon County schools, but judges in the other two judicial districts had ordered a start to desegregation in Birmingham, Huntsville and Mobile. Thirteen African American children were to begin classes at the formerly all-white Tuskegee High

School, and a smaller number of African American children had been admitted to white schools in the three urban centers. On the other hand, segregation still reigned supreme in over 100 school districts in Alabama. Patterson's strategy of leaving school segregation as a local matter might at least have preserved segregation in those other districts a while longer (Howard 2008:99-100; Walker 2009:156). Wallace, however, had achieved national notoriety and approval of most Alabama whites when he had stood in the school house door at the University of Alabama, and once again he chose to take the politically popular route, this time using force to keep black children out of white schools.

On September 2, 1963, Governor Wallace first issued an executive order requiring Macon County to delay the opening of Tuskegee High School for a week. This order was based on "conditions calculated to result in a disruption of the peace and tranquility of this State ... resulting from the threat of forced and 
unwarranted integration...” (Wallace 1963b). The school superintendent announced that school would open as scheduled, but the Governor then ordered his State Highway Patrol and members of the Dallas County Sheriff's Posse to surround Tuskegee High School and prevent students from entering. Although there were some calls for court action against the Governor, no party filed any papers at this point. The delay was only for a week, and the closing affected students of both races, so the interference with desegregation was minimal. However, another development would gravely endanger desegregation: a group of white parents set about to organize a white private school in Macon County, with full support from Governor Wallace and the promise of tuition grants from the state (Wallace 1963b).

After the one week delay, Governor Wallace issued three executive orders stating that no child shall be permitted to integrate the schools in Macon County, Birmingham, and Mobile. Unaware of the orders, the black students who had been admitted to Tuskegee High School met once again at the office of school superintendent Pruitt, who was "as cordial as he could be.” A black driver then drove them in a school bus to the school, where they were met by State Troopers. One Trooper boarded the bus, read the Governor's proclamation to the students and gave each a copy (Bagley 2012). At Tuskegee High School, Department of Justice attorney John Martin observed white children enter the school and saw the bus carrying African American children drive away after state troopers boarded it. 
He reported that there were no hostile crowds around the school, just newsmen (Martin 1963).

This was no longer just a school desegregation case. Suddenly, like the Little Rock case before it, it had escalated into a law enforcement issue. Could a Governor interfere with the efforts of these three school boards to comply with a federal court order? In response, the United States filed a new suit against Governor Wallace, state law enforcement officials, and the State of Alabama, to enjoin the interference in the three school systems. The United States sued "in its sovereign capacity to safeguard the due administration of justice in its court and the integrity of its judicial process.” Burke Marshall called the judges who had issued the Birmingham and Mobile orders, and, in an unprecedented move, although the case had been filed in Judge Johnson's judicial district, all the federal district judges from all three judicial districts in Alabama sat as a "five judge district court” (Bass 1993:209). Judge Johnson explained this demonstration of judicial creativity: "I presided in their presence and dictated the opinion, and they all signed it and went back home. There's no statutory basis or any other legal basis of which I'm aware that authorizes a five-judge District Court.” The solidarity of the five judges strongly displayed judicial determination to enforce Brown. The court in the Wallace case recognized the interest of the United States, ruling: 
[The United States] is suffering and, unless an injunction is entered, will continue to suffer immediate and irreparable injury as a consequence of the impairment of its judicial process, the obstruction of the due administration of justice in its courts, and the deprivation of rights under the Constitution and laws of the United States (U.S. v. Wallace 1963).

Wallace’s lawyer, John Kohn, lacking stronger arguments, argued that the Fourteenth Amendment, "conceived in hate, born in the aftermath of war, and carried through at the point of the bayonet,” was not valid (Bass 1993:211) and an injunction was in any event not necessary.

The court enjoined the Governor and his subordinates from interfering with school desegregation that had been ordered for that fall, and it ordered that they maintain law and order so that desegregation could move forward. The order more generally enjoined them from "[p]reventing, attempting to prevent, or interfering with the exercise of rights or the performance of duties under" the school desegregation orders of the three United States District Courts in Macon County, Mobile, and Birmingham (U.S. v. Wallace 1963). This order became the first step toward the eventual statewide injunction that would come four years later. More immediately, this time there was no stand in the schoolhouse door, and the black students began attending Tuskegee High School.

\section{ANALYSIS OF THE 1963 EVENTS}

This first phase reflects the complexity of the question of Brown's impact on meeting the goals of seekers of social change. The African Americans of 
Macon County had a thirst for education, fed at least in part by the legacy of Booker T. Washington. Their desire for equal education preceded Brown $v$. Board, but they viewed that decision as opening new opportunities. They wanted equal educational opportunity, and they saw desegregation as a route to achieve that end. In this $80 \%$ black county, face time with white children was at most a secondary goal. Practically, this meant that the seekers of social change had to make an initial choice, whether to use their limited resources to pursue school desegregation or to pursue voting rights. They lacked resources to pursue both simultaneously, and they chose voting rights, perhaps forced to do so by the Alabama legislature's gerrymander to exclude them from the municipal boundaries of Tuskegee, but also because they did view the vote as the right that would help secure other rights.

Next, having secured voting rights, the TCA asked the school board to desegregate; when the board failed to respond, TCA devoted its limited resources to employ Fred Gray to bring suit. The different actors held a variety of goals. The TCA's goals were focused on equal educational opportunities. Then Judge Johnson brought in the Department of Justice, which pursued at a minimum a law enforcement goal but perhaps also a desegregation goal. Judge Johnson was guided by the Supreme Court's decisions in Brown and subsequent cases. Once it was sued, the school district acquiesced in a desegregation order, perhaps influenced by the growing black vote or perhaps believing that compliance would 
be the best route to holding the school system together. Governor Wallace provided yet another perspective, one that was popular with most of the white electorate in Macon County and throughout most of Alabama: resistance. All the actors were aware that the ultimate target was the racial caste system.

\section{MORE INTERFERENCE, PRIVATE SCHOOLS, AND TRANSITION TO STATEWIDE CASE}

Having failed to halt the desegregation of the Macon County schools, Governor Wallace and his allies sought to undermine desegregation by creating a new school, private in theory but state-supported, for the white children of Macon County. And State School Superintendent Austin Meadows became increasingly vocal in discouraging local school officials from desegregating (Lee v. Macon County Board of Education 1965:U.S. Brief 13).

The first phase had begun with emphasis on achieving token desegregation, without saying much about the future. Would the Pupil Placement law still apply? What grades would be covered each year? How would the black schools become desegregated? What about faculty and transportation? Until the interference by the Governor and state school officials, all assumed that courtordered desegregation would proceed school system-by-school system rather than statewide. What in retrospect seems quite simple -- the absorption of a few more students into a white school -- was at the time a major, headline-grabbing issue. 
The thirteen black students at Tuskegee High School soon found themselves in all-black classes, as their white classmates of high school age transferred either to the other two white high schools in Macon County or to the newly-formed private segregation academy, the Macon Academy. Nonetheless, they felt that the teachers at Tuskegee High gave them a good education. Governor Wallace helped raise money for the Macon Academy and also (after the court had enjoined the school board from doing so) transported white students from Tuskegee High to the other white public high schools in Shorter and Notasulga. Moreover, in January 1964 the State Board of Education, in a serious misstep that violated the Patterson strategy of leaving school governance to the local school authorities, ordered that Tuskegee High be closed for lack of adequate enrollment and that its students (now all black) be sent to the black high school, Tuskegee Institute High (New York Times 1964).

Fred Gray, supported by the United States, asked Judge Johnson to enter a temporary restraining order against Governor Wallace and State Superintendent Austin Meadows, the two top officers of the State Board. Gray also challenged the constitutionality of their actions and of the state tuition grant statute which would help fund segregation academies such as Macon Academy. The court entered the TRO and assigned the black students to Shorter and Notasulga. Shorter High School desegregation occurred without incident, under guard of sixty Alabama state troopers. Notasulga’s desegregation met with initial 
resistance from the town's mayor until Judge Johnson enjoined him (U.S. v. Rea 1964).

In 1964 Fred Gray had not just sought relief for Macon County, nor did he confine himself to challenging the tuition grant statute. He relates that the “realization hit me like the burning bush speaking to Moses,” that if the Governor had the power to close a school in Macon County, "he should be compelled to use that same power to integrate all of the school systems in Alabama which were not already then under court order” (Gray 1995:213). So Gray added the Governor and other state officials as defendants and asked the court for statewide relief. The United States supported most of Gray’s motion but took a different approach to statewide relief, asking only that the court "enjoin the State Board to perform its constitutional obligation, within the limits of its state authority, to accomplish or facilitate the elimination of racial discrimination from the state school system." However, the United States expressed no view on the extent of the Board's authority -- a partial departure from the private plaintiffs' position (Barrett 1964). Alabama Attorney General Richmond Flowers argued that the Macon County Board had complied with the court's orders and that the plaintiffs had no right to expand the case beyond Macon County (Flowers 1964:Motion).

After a February 1964 hearing on Gray’s motion, the Department had filed a lengthy brief urging entry of a preliminary injunction running against both the Macon County officials and the defendant Alabama officials; asking that the 
grants-in-aid statute be declared unconstitutional as applied to grants for students at racially segregated schools, that the state officials be enjoined from interfering with desegregation in school systems in Alabama and be ordered to take affirmative steps to eliminate the dual school system in Alabama, "based not only upon the assumption and usurpation of authority by these officials but also upon the legal authority that they presently possess under Alabama law;” and that the Alabama Pupil Placement Law be declared unconstitutional "until the dual system of schools in Alabama is eliminated.” The brief described the evidence of the state's official policy of segregation, which created its dual system; the general control and supervision of the state superintendent and board over the local school systems and over the administration of the pupil placement act; their threat to pay tuition grants to students at Macon Academy and their active support of the Academy; and their interference with the federal court orders (U.S. Department of Justice 1964). The United States, in filing this brief, was inching closer to the plaintiffs’ position.

Because the case now challenged the constitutionality of a state law (the tuition grant statute), federal law at the time required that a three-judge district court be convened. Montgomery-based Judge Richard Rives of the Fifth Circuit and District Judge Hobart Grooms of the Northern District of Alabama, based in Birmingham were appointed to serve on the court with Judge Johnson. In July 1964 the three-judge court cautiously laid the foundation for sweeping statewide 
relief if the Governor continued on the course he had set, of interference with school desegregation. The court readily agreed that the Governor and State Board of Education had repeatedly interfered with the good faith efforts of the Macon County School Board to comply with the desegregation orders.

The court enjoined the State Board and Wallace (in his capacity as President ex officio of the State Board and not as Governor) from interfering with desegregation of Macon County schools. This seems to have been a symbolic show of deference to the office of Governor and also a warning shot that if Wallace persisted in his actions, the injunction would also run against him as Governor. The court also held that the state tuition grant law could not be used to finance the Macon Academy but it did not declare the statute unconstitutional in all circumstances. Plaintiffs had also challenged Alabama’s pupil placement law as unconstitutional. While agreeing that the school authorities had applied the law in a discriminatory manner in Macon County, the court declined to hold it unconstitutional "at this time," instead enjoining discrimination in the application of the law (Lee v. Macon County Board of Education 1964:756)

The novel and most consequential question before the court was whether to grant the plaintiffs' plea that it “order desegregation of all the public schools of the State of Alabama at the elementary and secondary level based upon the assumption or usurpation of authority by the Governor, the State Superintendent of Education and the State Board of Education....” The Governor argued that the 
local plaintiffs had no viable claim with respect to school systems outside Macon County. Here, the order making the United States not only amicus curiae but also a party became crucial. The court said that the United States was pursuing "the public interest in the due administration of justice in the Federal courts." Therefore, "the contention of the defendants that relief must be restricted only to these Negro plaintiffs borders on the frivolous.” Although it found that the State defendants' actions "place them in an extremely weak position," the court declined to enter the statewide desegregation order, saying instead:

For the present time this Court will proceed upon the assumption that the Governor, the State Superintendent of Education, and the State Board of Education will comply in good faith with the injunction of this Court prohibiting such interference with the local city and county school boards, and through the exercise of considerable judicial restraint, no statewide desegregation order will be ordered at this time. (Lee v. Macon 1964:756).

The court thus simultaneously showed restraint and deference to the State officials while also enjoining them from interfering with school desegregation anywhere in the State (Lee v. Macon 1964). To underscore that it would be holding the State officials' feet to the fire, the court also required that they use whatever control and supervision they exercised over local school districts "in such a manner as to promote and encourage the elimination of racial discrimination in the public schools..." (Lee v. Macon 1964:July 13 decree).

The opinion was squarely grounded on Brown, on three Supreme Court cases that had just been decided in May and June implementing Brown, and on six 
recent Fifth Circuit cases enforcing Brown. The court announced its ruling eleven days after the effective date of the Civil Rights Act of 1964, but no evidence points to any linkage between the two, and the court did not mention the Act in its opinion (Lee v. Macon 1964). The court had already issued a temporary restraining order in February and held a hearing in April, when the outcome of the legislation was still in doubt. The legislation, of which the judges obviously were aware, added nothing of immediate relevance to the issues before the court. In short, the orders against the state defendants, which in time would lead to statewide school desegregation, flowed from Brown, not from the Civil Rights Act of 1964.

School openings in Alabama, both in 1964 and 1965, occurred without major incidents and with slight increases in desegregation. By 196532 African Americans were attending formerly all-white schools and eight whites were attending formerly all-black schools in Macon County (Lee v. Macon 1967:U.S. Brief Appendix C, Table VI). Statewide, slightly over 1,000 African American students in Alabama (0.34\% of Alabama's black students) attended formerly allwhite schools in 1965 . Though one could rightly say this was a small and slow start, the courts had, with no help from Congress, broken the dikes guarding segregation of the schools. The orders of 1963 and 1964 would soon give rise to a flood of desegregation. 
1965 was a year of transition, when the federal government began large scale enforcement of provisions of the Civil Rights Act of 1964 relating to school desegregation. Some Alabama school systems showed a willingness to comply, but Governor Wallace and State Superintendent Meadows aggressively interfered with all such efforts. This led both the private plaintiffs in Lee v. Macon and the United States to seek statewide relief, which the court eventually granted in 1967. That part of the story must await another day.

\section{THE DISTRICT COURT AS AN AGENT OF SOCIAL CHANGE}

The story of Lee v. Macon shows that seekers of social change may achieve it through court action. The change may take longer than wished. It may not take the precise shape envisioned at the outset. Constraints on the courts do mean that they cannot create social change by themselves. And the norms that the Supreme Court establishes can profoundly affect the course of events. Even a reluctant executive branch may find itself enforcing the court's decrees, not because it agrees with them but because it recognizes the rule of law. Judge Johnson, building on what other judges had done in the Eisenhower administration, was able to marshal assistance from the Kennedy and Johnson administrations in Lee v. Macon by making the United States a party and amicus.

Social change is particularly difficult when prior court decisions have validated deeply embedded social practices in society and have created structural as well as cultural impediments to change. Southern whites knew that 
dismantling the dual school systems would upset the racial caste system. That system had ensured white dominance in education, in employment, in politics, and in social and economic affairs. As Judge Frank Easterbrook explained an analogous cultural phenomenon:

People taught from birth that black people are fit only for slavery rarely rebelled against that creed; beliefs coupled with the selfinterest of the masters established a social structure that inflicted great harm while enduring for centuries (American Booksellers $v$. Hudnut 1985:329).

So the white South saw Brown as an attack on a way of life, just as an earlier generation had viewed emancipation. African Americans saw it in much the same way. Although heavily black school systems would have few, if any, whites to provide an integrated education, black parents knew that desegregation could mean that their children could attend the closest school, study from the newer text books, ride on the good buses, have integrated faculty, compete in integrated athletic leagues, and advance to integrated universities, as Anthony Lee and Willie Wyatt did after graduation. The experience in Macon County fills out the picture found in the nationwide and regional statistics reflecting the extent of desegregation over time, that inform many studies of the impact of Brown (Rosenberg 2008:50-51; Klarman 2004:363). ${ }^{1}$

\footnotetext{
${ }^{1}$ This case study also informs the broader separation of powers consideration of the Supreme Court's ability to advance social change considered chiefly through statistical analysis of the influences on the court (e.g. Dahl 1957; Segal 1997; Epstein et al. 2001; Owens 2010).
} 
One should discount the courts as agents of social change if the evidence shows that the change would have taken place with or without judicial intervention or if one could show that change did not take place. So long as Plessy stood as both a symbol and a precedent, it was extremely unlikely that either Congress or the Southern States would bring about desegregation. This helps explain why neither the state nor federal governments moved to desegregate the schools. Nor did any school districts sue the state to overturn the segregation laws. Some northern states did pass civil rights legislation, and President Truman desegregated the armed forces (Kluger 1975:759; Klarman 2004:364). But against those who wished for school desegregation, Plessy was repeatedly cited not only to support the legality of state segregation laws, but also as a constitutional barrier to federal action. While Congress and the Executive need not have court approval to act within the scope of their authority, Congress' power to enforce the Fourteenth Amendment would not include the power to require desegregation so long as Plessy stood.

Separation of powers doctrine applies differently to court decisions interpreting the Constitution and those interpreting statutes. Congress may overturn the latter; it may not overturn the former, except by constitutional amendment or indirect means such as influencing the courts through its exercise of the advise-and-consent oversight of judicial nominees or adjusting the budget of the courts (Epstein \& Walker 2007:58-60, 123-124; Harvey \& Friedman 
2009:575-576; Eskridge 1991:679-680; City of Boerne v. Flores 1997:519). Drawing on the Spending Power, Congress could have imposed desegregation as a condition to receiving federal funds. However, it consistently rejected the Powell amendment, which would have forbidden race discrimination by school systems receiving federal funds (Rosenberg 2008:122-23). Not until 1965 was federal education spending a significant stick to coerce compliance with federal rules (Elementary and Secondary Education Act of 1965). Under Plessy the Southern states had created a complex arrangement of separate school systems, and societal reliance on the existing structure created a further barrier to change (Golden 1959:169-70). In the words of President Eisenhower (1955), "the practice of segregating educational facilities was authorized by the law of the land under Supreme Court ruling, from 1896 to 1954 . Under that ruling ..., customs were established in certain sections of our country which have been repudiated and declared illegal by the Supreme Court ruling of 1954.” Plessy not only stamped segregation with legality but also stamped it, in the eyes of most Southern whites, as moral (Briggs v. Elliott 1951:537; Davis v. County School Board of Prince Edward County 1952:339). Thus, the need for the Brown decision stemmed not just from the growing desire for social change, but also from the substantial barriers to social change so long as Plessy's application to public schools remained good law. 
Although Brown faced the challenges of the "constrained court," Lee v. Macon provides a vivid example of those challenges being overcome without aid from Congress. Lee v. Macon did not stand alone in 1963, as desegregation began or continued in every state except Mississippi even though it was widely believed that President Kennedy’s proposed Civil Rights Act had little chance of passing (Greenberg 1994:254-55; The Alabama Council on Human Rights, et al. 1972:1). The constraints on the courts did slow down judicial action, as prospective plaintiffs struggled to find lawyers, decisions of reluctant trial courts went through the appeals process, and determined defendants used every possible tool to delay. But in the fullness of time, the lower courts did enforce Brown and the school districts did comply. A final constraint here was the culture of the white minority. If the objective of the plaintiffs was to end racial isolation, the flight of whites to private schools did defeat meeting that goal in Macon County, at least for a time.

Did Brown cause change? Those who deny that it did cite the long delay between the Brown decision in 1954 and the desegregation of public schools in the Deep South (Rosenberg 2008:52) and statistics showing that many black students still attend virtually one race schools. Not until after the executive branch and the Congress got involved did the Deep South desegregate its public schools. However, the border states did, either voluntarily or as a result of litigation, make significant progress in compliance during that ten-year period from 1955 to 1964 (2008:103-104). While African Americans filed few 
desegregation suits in the Deep South from 1954-1964, Brown energized the African American community to seek desegregation of buses, parks, libraries, zoos, and other public facilities (Brown-Nagin 2011:432-34). More important, it became a central element in the ideology of the civil rights movement. As Dr. Martin Luther King, Jr. (1964:83) said, “Thus it is that I can urge man to obey the 1954 decision of the Supreme Court, for it is morally right; and I can urge them to disobey segregation ordinances, for they are morally wrong.”

Change did come slowly. A court may issue a decree, but that does not necessarily bring about instant change. Taking a long view, though, the combination of the voting decrees and the school desegregation decrees led to the end of the racial caste system in Macon County. The black residents of Macon County had to prioritize how to use their limited resources. Their focus on gaining a measure of political power resulted in the all-white school board taking a moderate stance on desegregation, but the school board had no control over the actions of state officials or of the parents of white students. Change through the ballot box would not become feasible until after passage of the 1965 Voting Rights Act. Even then black voters were in the minority in every state; their electoral influence in the South was scattered at best until after the 1970 decennial census, the first time that the Act was applied to redistricting. Not until after the Voting Rights Act amendments of 1982 banned state voting laws that resulted in 
diluting the vote based on race did racial fairness in districting become the general rule.

In the process the TCA made contact with the federal government, and the connections made during the voting rights case helped solidify the ability of the Department of Justice to help bring about school desegregation, first in planning for a peaceful school opening, then as a defender of the court order against outside interference, and ultimately as a shaper of substantive positions on such issues as tuition grants, the content of desegregation plans, and the contours of statewide relief. Judge Johnson's bold action in designating the United States as a party removed one of the major constraints on judicial power.

Brown was a necessary, if not sufficient, prerequisite to change. Macon County African Americans turned to the federal court because they had nowhere else to turn. Their petitions to the school board went unanswered, as did similar petitions in over a dozen Alabama school districts in 1954 and 1955 (Bagley 2013:29-31). Even if the district wished to desegregate, it could not do so, since Alabama law forbidding desegregation was consistent with Plessy. A request to the State of Alabama for relief would have fallen on antagonistic ears. Nor is there any evidence that changing attitudes might have led to change in ten, twenty, or thirty years after 1954. So although compliance with Brown was slow in coming, it was faster than reliance on change at the state level. Finally, change was unlikely to come from the other branches of the federal government, 
constrained as they were by the Plessy decision and the political strength of the white "Solid South.”

Seekers of social change must engage in a calculus, reviewing their options and often being forced to choose among limited ones. For them, the federal courts, however constrained they may be, have one advantage that the other two branches and the state governments do not have: they are not captives of the prevailing majority will of the moment but instead answer to the larger values embedded in the Constitution.

It is difficult to see how change would have come to Macon County without federal court intervention. Sam Engelhardt and those like him ran Macon County and dominated the Alabama legislature. Civil rights activists needed support from the courts and the federal government, so change from within had little chance. In such a situation, the natural place to turn is Congress. Yet, despite demands from civil rights groups, Congress rebuffed efforts to authorize the Attorney General to sue for school desegregation. Congress, neither resisting nor promoting desegregation, showed no leadership on this issue, because the Southern committee chairs and caucus in the Senate were too strong and unyielding on most race issues. The backbone of segregated schools in Alabama was broken by Lee v. Macon and other cases in 1963, before Congress had acted. 


\section{CONCLUSION}

Brown and its aftermath show the complexity of social change, especially when change meets strong resistance. But this history also suggests that the courts often have the competence to deal with that complexity and to lead the way for other essential actors. Yet one should also note the negative side: The courts can be not only agents of change but also agents of the status quo. They can validate laws that entrench the status quo, as they did in the years after Plessy. And they can effectively block or at least delay performance of the other branches’ reform agenda. Opponents of social change often mobilize to challenge it in the courts.

In short, if we speak of the "constrained court," we must also speak of the “constrained executive” and the “constrained Congress” (Schultz \& Gottlieb, 1996:67) and we must acknowledge that those judges who are willing to enforce unpopular laws wield many tools of a dynamic court. Before Brown, school segregation was an entrenched social custom that could be undone only through state legislation, a most unlikely avenue for change, in light of the entrenched racial caste system. Brown transformed school segregation into an issue of whether the Constitution would be enforced. Ultimately, Brown succeeded because it lent formal legitimacy to the opponents of school segregation, empowered the lower courts and the executive and put pressure on the Congress. Lacking authority from Congress to bring school desegregation cases, the 
Department of Justice enforced desegregation orders once they were entered and gained legitimacy as a party with the rights of a plaintiff, from orders such as Judge Johnson's order conferring that status. Congress acted only after the lower courts had already begun the process of desegregating schools in the Deep South.

\section{Works Cited}

The Alabama Council on Human Rights, et al. (1972) “It's Not Over in the South: 'School Desegregation in Forty-three Southern Cities Eighteen Years After Brown.",

Bagley, Joseph M. 2012. Interview of Willie Wyatt at Stone Mountain, Georgia, 4 Jan.

Bagley, Joseph M. (2014) “School Desegregation, Law and Order, and Litigating Social Justice in Alabama, 1954-1973” Approved, unpublished PhD. diss., Georgia State University.

Barrett, St. John (1964) Memo to Burke Marshall, Feb. 17. DOJ file 144-100-21, National Archives and Records Administration [NARA], College Park, Md., box 1, section 1 .

Bass, Jack (1993) Taming the Storm. New York: Doubleday.

Brown-Nagin, Tomiko (2011) Courage to Dissent: Atlanta and the Long History of the Civil Rights Movement. New York: Oxford University Press.

Brownell, Herbert (1956) Letter to Chairman and Members of the Anderson County Board of Education, Clinton, Tennessee sent December 4.

Buford, K.L. (1959) Letter to William Rogers, Jan. 6. Tuskegee Institute Archives, Tuskegee Civic Association files, Box 14, folder 12.

Carr, Robert K (1947) Federal Protection of Civil Rights: Quest for a Sword. Ann Arbor: University of Michigan Press. 
Cash, W. J. (1941) The Mind of the South. New York: Doubleday Anchor Books.

Cobb, Dan (1951) "Macon Negroes demand equal school rights.” Birmingham News, 10 Feb.

Cummings, Scott L. (2013) "Empirical Studies of Law and Social Change: What is the Field? What are the Questions?” 2013 Wisconsin Law Rev. 171-204.

Dahl, Robert A. (1957) “Decision-Making in a Democracy: The Supreme Court as a National Policy-Maker,” 6 J. of Public Law 279-295.

Doar, John (1963) Memo to Marshall: "Report on Status of School Desegregation - Macon County, Alabama,”sent 26 Aug. JFK Papers, Burke Marshall Collection, Box 21.

Eisenhower, Dwight D (1965) Letter to Governor Byrnes. Vol. 12 \#86 Eisenhower Presidential Library, Official Files Collection Box 430 File 102-B-3[5][3]. Reproduced in Belknap, Michal R. (ed.) (1991) Civil Rights, the White House, and the Justice Department, 1945-1968, vol. 12. New York: Garland Publishing at 286-288.

Epstein, Lee, Jack Knight, \& Andrew D. Martin (2001) “The Supreme Court as a Strategic National Policymaker,” 50 Emory Law J. 583-611.

Epstein, Lee \& Thomas G. Walker (2007) Constitutional Law for a Changing America: Institutional Powers and Constraints. 6th ed. Washington. D.C.: CQ Press.

Eskridge, William N. (1991) "Reneging on History? Playing the Court/Congress/President Civil Rights Game,” 79 California Law Review 613-684.

Eyes on the Prize (1985) Interview with John Doar, 15 Nov. Available at http://digital.wustl.edu/cgi/t/text/text$\underline{\mathrm{idx} ? \mathrm{c}=\mathrm{eop} ; \mathrm{cc}=\mathrm{eop} ; \mathrm{rgn}=\text { main;view=text;idno=doa0015.0543.028. }}$.

Flowers, Richmond M. (1964) Motion as Attorney General of the State of Alabama, served 18 Feb. DOJ file 144-100-2-1, National Archives and Records Administration [NARA], College Park, Md., box 1, section 1. 
Golden, Harry (1959) For 2థ Plain. Cleveland: World Publishing Co.

Gomillion, Charles G. (1959) Letter from C.G. Gomillion to The Southerner, 7 Mar.

----- (1963) Letters to I.V. Billis and others [including the Lees] and to Mr. and Mrs. Nelson Boggan and others, January.

Gray, Fred (1995) Bus Ride to Justice. Montgomery: New South Books.

Greenberg, Jack (1994) Crusaders in the Courts: How a Dedicated Band of Lawyers Fought for the Civil Rights Revolution. New York: Basic Books.

Greene, Harold (1963) Letter to Ben Hardeman, 12 Feb. DOJ file 144-100-2-1, National Archives and Records Administration [NARA], College Park, Md., box 1, section 1 .

Guzman, Jessie P. (1984) Crusade for Civic Democracy. New York: Vantage Press.

Hall, Matthew E. (2011) The Nature of Supreme Court Power. New York: Cambridge University Press.

Hamilton, Alexander (1788) “The Federalist No. 78.” Reproduced in The Federalist Papers, ed. Clinton Rossiter. New York: New American Library (1961). Also available at http://www.constitution.org/fed/federa78.htm.

Harris, Mac (1963) “Integration Shift Wins Macon Okay.” Montgomery Advertiser, 30 Aug.

Harvey, Anna \& Barry Friedman (2009) "Ducking Trouble: Congressionally Induced Selection Bias in the Supreme Court's Agenda,” 71 J. of Politics 574-592.

Howard, Gene L. (2008) Patterson for Alabama: The life and career of John Patterson. Tuscaloosa: University of Alabama Press.

Johnson, Charles S. (1934) Shadow of the Plantation. Chicago: University of Chicago Press. 
King, Martin Luther, Jr (1964) “Letter from Birmingham Jail” in Why We Can't Wait. New York: Harper \& Row.

Klarman, Michael J. (2004) From Jim Crow to Civil Rights: The Supreme Court and the Struggle for Racial Equality. Oxford: Oxford University Press.

Kluger, Richard (1975) Simple Justice: The History of Brown v. Board of Education and Black America's Struggle for Equality. New York: Knopf. Revised and expanded ed. 2008. New York: Knopf.

Landsberg, Brian K (2013) Symposium: Voices of the Civil Rights Division: Then and Now (October 28, 1011). 44 McGeorge Law Rev. 269.

Legislative Reference Service (1954) “The School Segregation Problem.” Montgomery Alabama, 9 Jan. Describing how desegregation might be delayed or averted.

Mack, Kenneth W. (2012) "Law and Local Knowledge in the History of the Civil Rights Movement.” 125 Harvard Law Rev. 1018-1040.

Martin, John (1963) Affidavit attached to complaint in U.S. v. Wallace, C.A. 1976-N (M.D. Ala.) 9 Sept.

Marshall, Burke (1963) Memorandum for the Attorney General, Monday Report. Feb. 11. John F. Kennedy Presidential Library Archives, Burke Marshall Papers, Box 001.

McCann, Michael W (1992) “Reform Litigation on Trial.” 17 Law \& Social Inquiry 715-743.

------ (1994) Rights at Work. Chicago: University of Chicago Press.

New York Times (1964) “Six Negroes Barred at Alabama School.” Published 6 Feb.

Norman, David L. (1963) Memo to St. John Barrett, 15 Aug. DOJ file 144100-2-1, National Archives and Records Administration [NARA], College Park, Md., box 1, section 2. 
Norrell, Robert J. (1985) Reaping the Whirlwind: The Civil Rights Movement in Tuskegee. Charlottesville: University of Virginia Press.

Owens, Ryan J. (2010) "The Separation of Powers and Supreme Court Agenda Setting,” 54 American Journal of Political Science 412-427.

Peltason, J.W. (1961). 58 Lonely Men: Southern Federal Judges and School Desegregation. New York: Harcourt, Brace \& World, Inc.

Rosenberg, Gerald N. (2008) The Hollow Hope: Can Courts Bring About Social Change? 2nd ed. Chicago: University of Chicago Press.

Schultz, David \& Stephen E. Gottlieb (1996) "Legal Functionalism and Social Change: A Reassessment of Rosenberg's The Hollow Hope: Can Courts Bring About Social Change?” 12 Journal of Law \& Politics 63-91.

Segal, Jeffrey A. (1997) "Seperation-of-Powers Games in the Positive Theory of Congress and Courts,” 91 American Political Science Review 28-44.

Taylor, Fred (1951) “Juicier Plums Wanted.” Birmingham News, 11 Feb.

“Thirty-Two Negroes Ask School Desegregation in Macon County” (1955) Birmingham World, July 22.

Tuskegee Civic Association (1950) "Trends in Selected Aspects of Public Education for Negroes in Macon County, Alabama, 1938-39; 1943-44; 1948-49.” Tuskegee Institute Archives, Tuskegee Civic Association files, Box 1, folder 11.

----- (1965) “Eighth Anniversary Celebration: Crusade for Citizenship,” 29 June. Tuskegee, AL: Tuskegee Civic Association.

Tuskegee News (1963) 15 Aug., p. 1. JFK Papers, Burke Marshall Collection, Box 21.

U.S. Department of Justice (1964) Memorandum Brief of the United States in Support of Plaintiffs’ Motion for a Preliminary Injunction, 13 Mar. DOJ file 144-100-2-1, National Archives and Records Administration [NARA], College Park, Md., box 1, section 1. 
Vecera, Vincent (2014) “The Supreme Court and the Social Conception of Abortion” 48 Law \& Society Review 345-375.

Walker, Anders (2009) The Ghost of Jim Crow: How Southern Moderates Used Brown v. Board of Education to Stall Civil Rights. New York: Oxford University Press.

Wallace, George C. (1963a) Governor’s Inaugural Address, January 14. Alabama Department of Archives and History, http://www.archives.state.al.us/govs_list/inauguralspeech.html, viewed on 15 Aug. 2012.

----- (1963b) Governor of Alabama Executive Order, 2 Sept.

\section{Cases Cited}

American Booksellers v. Hudnut, 771 F.2d 323 (7th Cir. 1985), aff'd, 475 U.S. 1001 (1986).

Bell v. State of Maryland, 378 U.S. 226 (1964).

Briggs v. Elliott, 98 F.Supp. 529 (E.D. S.C. 1951), vacated, 342 U.S. 350 (1952).

Brown v. Board of Education of Topeka Kansas, 347 U.S. 483 (1954). (Brown)

Brown v. Board of Education of Topeka Kansas, 349 U.S. 294 (1955). (Brown II)

Bush v. Orleans Parish School Board, 191 F.Supp. 871 (E.D. La. 1961).

City of Boerne v. Flores, 521 U.S. 507 (1997).

Davis v. County School Board of Prince Edward County, 103 F.Supp. 337 (E.D. Va. 1952), rev'd, Brown v. Board of Education of Topeka, Kansas, 349 U.S. 294 (1955).

Lee v. Macon County Board of Education. 221 F.Supp. 297 (D.C. Ala. 1963).

Lee v. Macon County Board of Education, 231 F.Supp. 743 (D.C. Ala. 1964).

Lee v. Macon County Board of Education, 267 F.Supp. 458 (D.C. Ala. 1967), aff'd, Wallace v. U.S., 389 U.S. 215 (1967) (structural injunction case). 
Plessy v. Ferguson, 163 U.S. 537 (1896).

U.S. v. Madison County Board of Education, 219 F.Supp. 60 (N.D. Ala. 1963), aff'd, 326 F.2d 237 (5th Cir. 1964), cert. denied, 379 U.S. 929 (1964).

U.S. v. Rea, 231 F.Supp. 772 (M.D. Ala. 1964).

U.S. v. Wallace, 222 F.Supp. 485 (M.D. Ala. 1963) (five judge district court).

\section{Legislative Acts}

Civil Rights Act of 1964, Pub. L. No. 88-352, 78 Stat. 241 (1964) (codified as amended in scattered sections of 2 U.S.C., 28 U.S.C., and 42 U.S.C.).

Voting Rights Act of 1965, Pub. L. No. 89-110, 79 Stat. 437 (1965) (42 U.S.C. §§ 1971, 1973a-p (Supp. I, 1964)).

Voting Rights Act Amendments of 1982. Pub. L. No. 97-205, 96 Stat. 131 (1982) (codified in scattered sections of 42 U.S.C. $\S \S 1973$ to 1973aa-6 (1982).

Brian K. Landsberg is Distinguished Professor of Law at Pacific McGeorge School of Law. He is the author of Enforcing Civil Rights, Race Discrimination and the Department of Justice (1997) and Free at Last to Vote, The Alabama Origins of the 1965 Voting Rights Act (2007). He served as an attorney in the United States Department of Justice, Civil Rights Division, from 1964 until 1986. His current research explores the institutional, legal, and theoretical facets of school desegregation litigation, through the lens of Lee v. Macon County Board of Education. 